\title{
DEVELOPMENT OF THE SETTLEMENT SYSTEM IN THE OSTRAVA AGGLOMERATION AND POSSIBILITIES OF ITS RESTRUCTURING
}

\begin{abstract}
A. V a is h a r: Development of the settlement system in the Ostrava agglomeration and possibilities of its restructuring - Geografie - Sborník ČGS, 107, 2, pp. 171 - 188 (2002). Large-scale coal-mining.regions were showing specific settlement from the 19th century. The original typical system with towns as centres and their hinterlands was remodelled to a mosaic of coal pits, miner colonies (later housing quarters) and industrial factories interwoven with a dense web of infrastructure. The region of Ostrava is one of examples; here the mining of black coal linked up with the metallurgy of iron, heavy engineering and chemical industry. The region's economic base has experienced a restructuring in connexion with social changes after the year 1989 with individual towns seeking new functions and place in the system of settlement.

KEY WORDS: settlement system - Ostrava agglomeration (Czechia) - coal mining and metallurgy restructuring.

The work is a partial output of research implemented within a grant project No. S-3086005 funded by the Grant Agency of the Academy of Sciences of the Czech Republic with the name "Effect of suppressed deep coal-mining on phenomena in lithosphere and environment", which at the same time links up with the key project of scholarly research No. K-3046108 solved in the Academy of Sciences of the Czech Republic with the name "Impact of climatic and anthropogenic factors on live and lifeless environments".
\end{abstract}

\section{Specific features of settlement in mining regions}

A stranger driving through the coal-mining region would easily lose his sense of direction being accustomed to the typical signs of drawing nearer to a town centre or leaving it behind. Extensive basins with either formerly or still existing coal mining show a specific structure of settlement, which is somewhat beyond the typical conception of arrangement of seats in centres. On the opposite, the landscape is characteristic of a seemingly chaotic alternation of seats, shafts, industrial and infrastructural premises, and mine dumps or landfils with industrial waste. The mine pits used to be once of central importance with all other activities concentrating in their neighbourhood. The layout of mines naturally depends on the localization of raw material.

The atypical structure of seats began to form at the time when the development of technologies required to change the energy base. Transition of the industry from wood to coal as a main raw material for energy in the 19th century entirely transformed the original structure of settlement in large basin areas. Extraction of coal was soon followed by developing heavy industries, metallurgy in particular. The basins became regions of conclusive 
importance for their countries. However, their economic prosperity was at a cost of serious environmental problems.

The situation began to change in the second half of the 20th century when the new technologies brought a changed orientation of the industry. Progress was no more measured by tons of steel produced or consumed $\mathrm{kW}$ hours of electric energy but rather by the level of cybernetization, automation and miniaturization, which reduced coal and steel demands and made the coal basin regions face a problem of restructuring their economies. Furthermore, the number of people employed in the industry began to be generally falling to the benefit of services with industrial towns appearing in the stage of desindustrialization (Pacione 2001). And because the structure of settlement created during the last 150 years corresponded almost exclusively to the purposes of coal extraction, the issue of restructuring the system of settlement became pressing too - naturally together with the issue of revitalization of environment in the coal mining regions.

The most popular European regions of this type are the Ruhr Basin in Germany (Dürr-Grame 1993), the Midlands in England (Burdack 1993), Donbas in Ukraine or Upper Silesia in Poland (Klosowski-Runge-Prokop 1997). The last mentioned region links up with the Ostrava region on the Czech side of the border, whose settlement is a subject of this paper (Fig. 1). A specific feature of coal basin regions in post-socialist countries is the fact that the centrally-planned economy was not capable to respond in time to modern industrial technologies, conserving to a considerable extent the outdated models of manufacture. This is why the changes experienced by westEuropean coal basin regions several tens of years ago have to be faced by the Ostrava industrial conurbation in an even more urgent form at the beginning of the 1990s.

The following contribution will try to suggest an answer to the question of what is going to be the way in which the settlement in the Ostrava region will

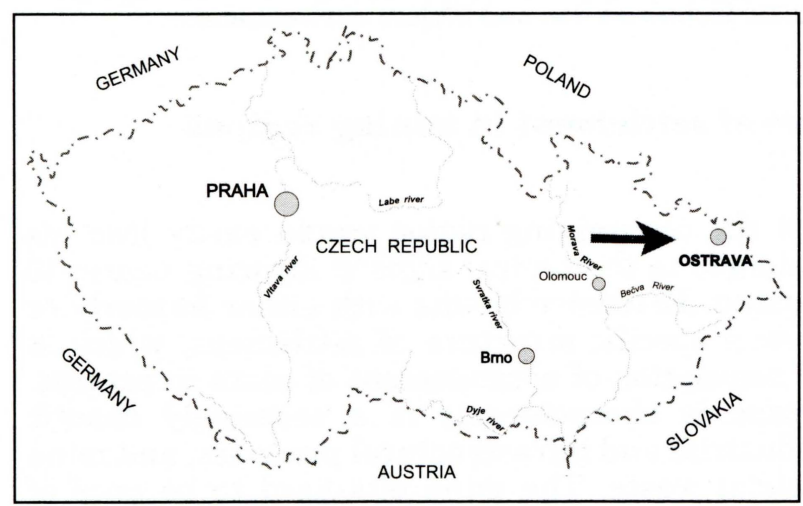

Fig 1 - Situation of Ostrava within Czechia cope with the economic restructuring occurring in the area. The settlement, which had shown typical symptoms of central system, based on the network of small towns in a marginal region, before the beginning of mining, was substantially changed by the extreme industrialization. The way of the course of its adaptation to new conditions after the finishing the mining activity is the question. It is interesting to observe, to which extent the functions of original centres of the settlement system can be restored, how the functions of the current middle-size towns will change and which place in the national settlement system the centre of the whole region - the city of Ostrava will shift. 


\section{Historical development of the Ostrava conurbation}

The agglomeration of Ostrava encompasses the city of Ostrava itself, the Karviná district and parts of the districts Frýdek-Místek, Nový Jičín and Opava (Fig. 2). One of geographers studying the history of settlement in the Ostrava region was for example Charvát (1992). Prehistorical settlement in the

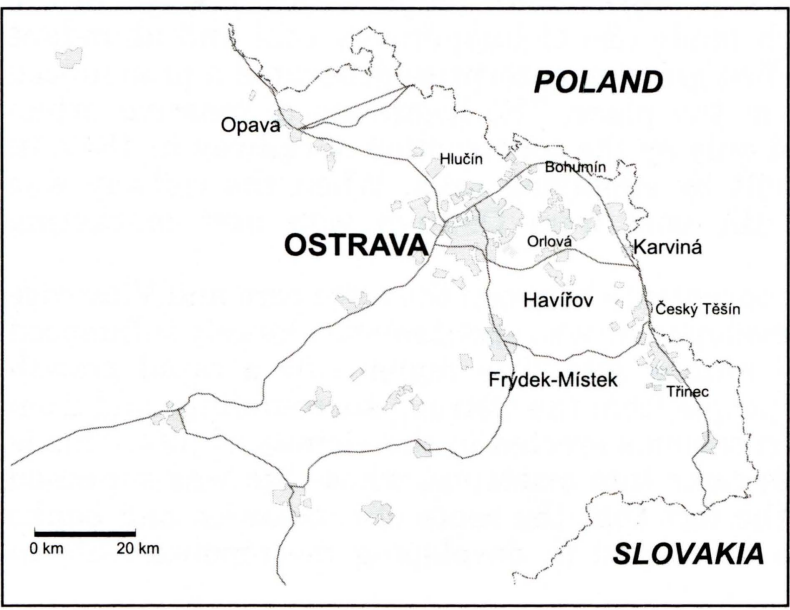

Fig. 2 - The Ostrava agglomeration Ostrava region made use of the strategic hill Landek where a site of fortified settlement came into existence. However, any more important settlement did not develop in the area the reason being a considerable waterlogging of the floodplain and the peripheral location on the boundary between the Czech and Polish states. Relatively distant greater centres were Opava in the west and Těšín in the east.

A detailed characteristic of modern urbanistic development was worked out by Kuča (2000). The rural and fishermen's village Ostrava situated on the left bank of the Ostravice River is assumed to exist on the turn of the 12th and 13 th centuries. From about 1279 Ostrava was an episcopal town and a no big centre of the northern portion of the Hukvaldy estate. The localization of Ostrava, stretching extremely to the North has a strategic reason as a counterweight to the castle in Silesian Ostrava and to the royal castle of Landek with the aim of controlling the trade path between Těšín and Opava. Unlike some other towns in the surroundings, Ostrava was spared during the Hussite and Czecho-Hungarian wars this strengthening its function as a centre based on market activities. Draper's trade started to grow from the mid-15th century. The population doubled to two thousand in the course of the 16th century.

A decline of Ostrava occurred in the 17th century its reason being a combination of unfavourable circumstances including plague (1625), consequences of the 30-year war, big fire (1675) and disgrace of estate lords. The decline went on also in the first half of the 18th century when the region suffered a repeated attack of plague taking turns with fires and floods. A great loss was the rerouting of the road from the Moravská brána (Gate) to Cracow bypassing Ostrava due to unfitted passage over the often flooded Ostravice River. The decline culminated in the annexation of a major part of Silesia by Prussia. This was a final disconnection of the remaining road from Opava to Těšín through Hlučín and Ostrava appeared on the state border. The number of its inhabitants dropped below a thousand.

The situation of Ostrava began to improve only after Galicia had been annexed to the Habsburg monarchy. The customs boundary ceased to exist and the Ostrava region became a centre for marketing Galician cattle. This however resulted in a disastrous hygienic situation. The first half of the 19th 
century was in token of changing character of housing in Ostrava where stone or brick buildings started to prevail. A new road was built from Opava via Ostrava to Těšín and it was in connexion with this new route that a slow urban development slowly came to Silesian Ostrava too.

Regular extraction of black coal on Landek's foothills was launched in the year 1782. Mining in the territory of Silesian Ostrava exhibited higher volumes. In 1828 the Rudolf iron works were founded (predecessor of the Vítkovice Steel Works), which made use of high-energy coal and abundant water in the Odra River. The fast growing enterprise generated a pronounced demand for black coal right at the place. The beginning of massive urban changes was however induced only by the construction of railway in 1847, in which Ostrava marked a profit by supplying rails. When the railway was extended to Lvov in 1861, the coal from Ostrava won new marketing opportunities.

Heavy industry started to concentrate between the town core and Vítkovice from the 1840s. The urban development was spontaneous, largely influenced by the location of individual mining pits. The region saw a rapid growth thanks to the immigration of people from the Ostrava surroundings and from Galicia. Miners were seated in colonies erected in the vicinity of pits. This is how a mosaic of isolated seats came into existence, whose life was supposed to be temporary. Regarding the fact that the seats of companies and banks were in Vienna, nobody was interested in developing metropolitan life in Ostrava.

At the turn of the 19th and 20th centuries, Ostrava experienced a greater establishment of mid-classes, which instigated the development of metropolitan housing which was however limited by the preceding chaotic exploitation of the territory. There were apartment houses, public buildings and cultural infrastructure coming into existence. However, the immediate southern surroundings of the town core were affected by mining and industrial activities. Poor quality houses in the centre were rehabilitated and reconstructed after 1903. In 1900, Ostrava became a seat of the political district. This time saw another dramatic development and concentration of mining and industrial activities, power and chemical industries. The Vítkovice steel works were expanding. Environment was severely affected.

The end of monarchy was a main reason for seats of industrial corporations being moved directly in Moravian Ostrava and the industrial importance of the town further grew under the $1^{\text {st }}$ Czechoslovak Republic. The housing standard improved, mainly thanks to the building of one-family houses in suburbs. The individual seats started to get closer to each other with their housing estates, which was further favoured by a good system of transport. Extended technical infrastructure helped to improve water supply. The metropolitan transformation of Ostrava was accomplished and its symbol became a newly built town hall.

Munich 1938 meant a short-time period of stagnation for Ostrava, which was at the time split into three states and nearly cut-off from the rest of Czechoslovakia. On the other hand, the period of protectorate raised the city of Ostrava to an important place in the war machinery. The whole town was unified into a single administrative unit. A new metallurgical combine started to be built in Kunčice. Housing started to be developed. At the end of the war, Ostrava was damaged by bombing and war operations.

After the war, Ostrava was one of priorities. Due to the transfer of Germans and war events, the town had to face a lacking labour force. This 


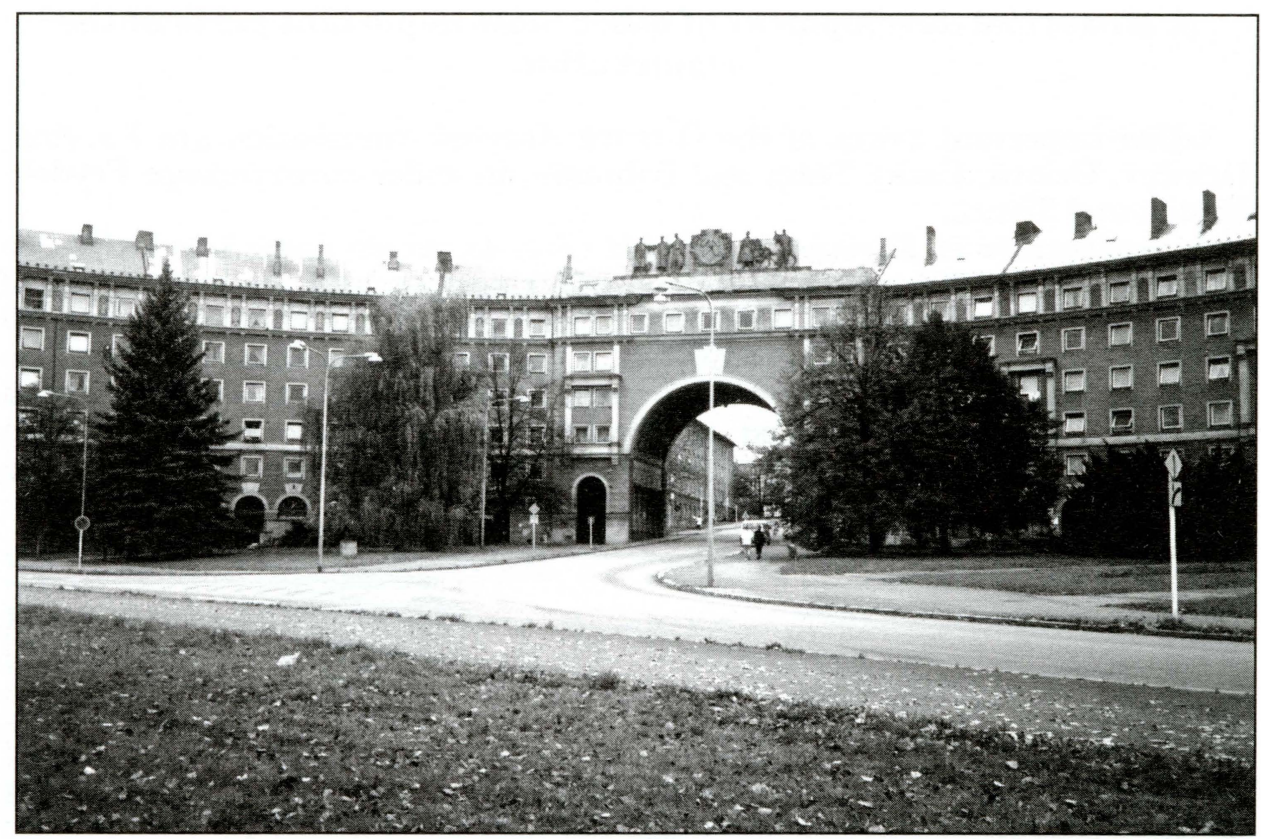

Fig. 3 - Ostrava - Poruba: a monumental architecture according to the soviet model (Photo by A. Vaishar)

was one of reasons to start building housing estates. The first of them was Zábřeh and later Poruba (Fig. 3), erected in the western part of city limits in the spirit of so called socialist realism. Nová hut steel works were put into operation at the beginning of the 1950s. The population began to move to the housing estates built of pre-fab blocks of flats while the traditional parts of the town showed a stagnation.

Erection of housing estates went on during the whole socialist period. Important was especially the southern direction serviced by a new WE communication Rudná and a road artery leading to the Mošnov Airport, which joined Ostrava with the rest of Moravia. Poruba reached 100000 inhabitants and there was a campus of the High School of Mining and a regional hospital built on its periphery. Building of the neighbourhood Fifejdy started in 1969 and some areas of lower urban quality situated to the north of the town core were rehabilitated. The rehabilitation was however not used for housing of mature conception. The Cerná halda (Black spoil bank) to the south of the centre were recultivated and later served as a site to erect the Ostrava Exhibition Centre. The internal structure of Ostrava in the comparison with Katowice was studied by Vystoupil and Wecławowicz (1987).

Coal mining in Ostrava ended in the 1990s. Problems of restructuring induced a pressing economic situation and high unemployment. Hypermarkets, banks and other commercial buildings are the most characteristic urbanization feature of the last decade. Problematic is the stormy development of individual motoring, which calls for new traffic solutions. 


\section{Historical development of other most important parts of the conurbation}

Other important towns of the Ostrava-Karviná conurbation are Karviná, Havířov, Orlová, Český Těšín and Bohumín, in wider surroundings FrýdekMístek and Třinec.

A predecessor of Karviná is Fryštát (Fig. 4), which came into existence before the year 1305 on a vague mountain ridge between the watersheds of Olše R. and Petrůvka R. as a location town to secure the northern boundary of the Těšín principality. Fryštát was a centre of rural hinterland for the entire period of Middle Ages its character being that of a small town with a chateau that was later added an extensive park which was in the 19th century linked up with the spa premises of Darkov. Fryštát stood outside the major urbanization activities until the mid-20th century.

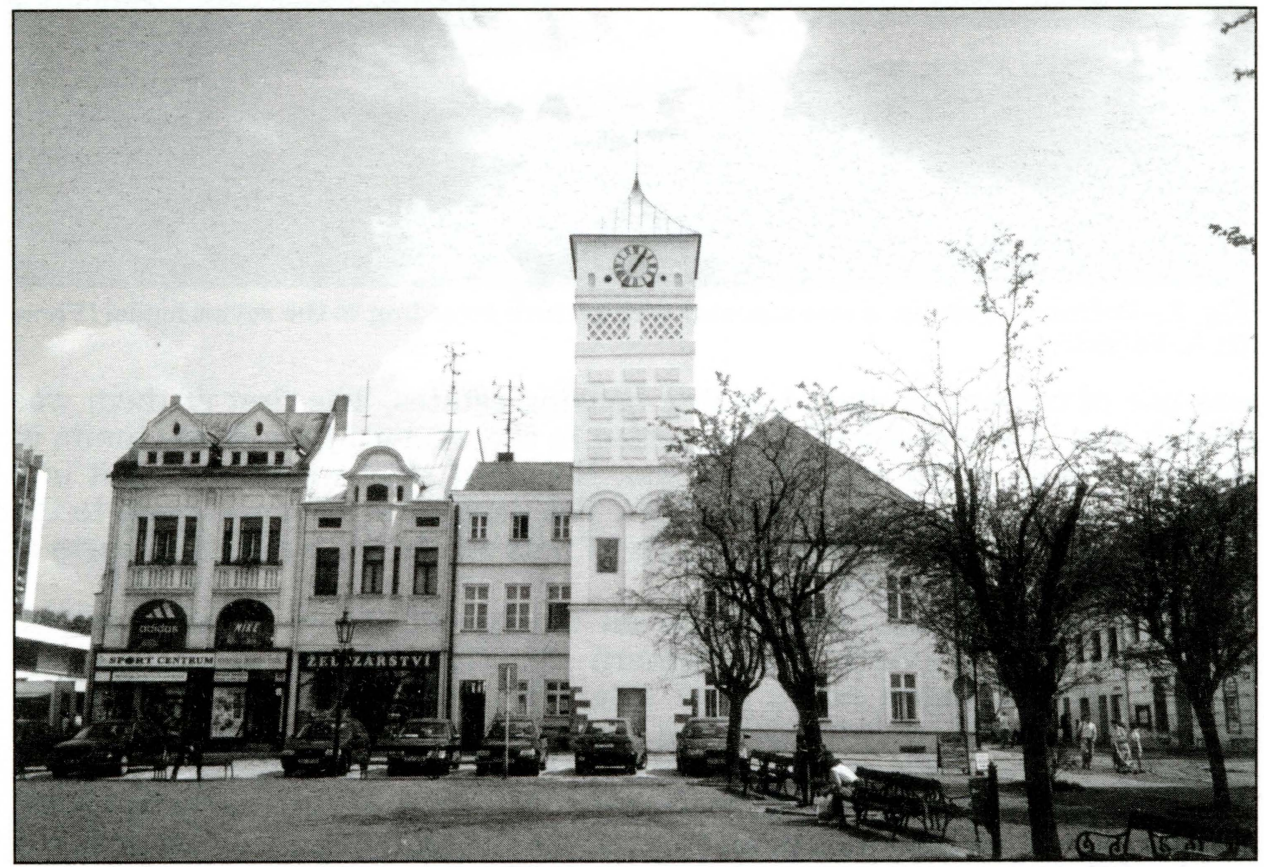

Fig. 4 - Karviná: the old center of Fryštát (Photo by A. Vaishar)

The beginning of building Karviná falls into the year of 1947 when the first satellite housing estate in the Ostrava region was founded to the north-west of Fryštát. The centre of construction works on new housing estates moved to the east in the period between the 1960s - 1980s. In 1963, the town happened to appear on the main branch of the railway track leading from Bohumín to Košice, which was rerouted due to undermining of the original route. The housing estate of Hranice was linked up with the complex of new spas in Darkov (Fig. 5).

Despite the intensive mining, building of pre-fab blocks of apartments and realigned communications, the original urbanistic character of Fryštát with its chateau, old Darkov spa and a small suburb of one-family houses remained preserved and became a zone of urban monument. This core was a base to be 


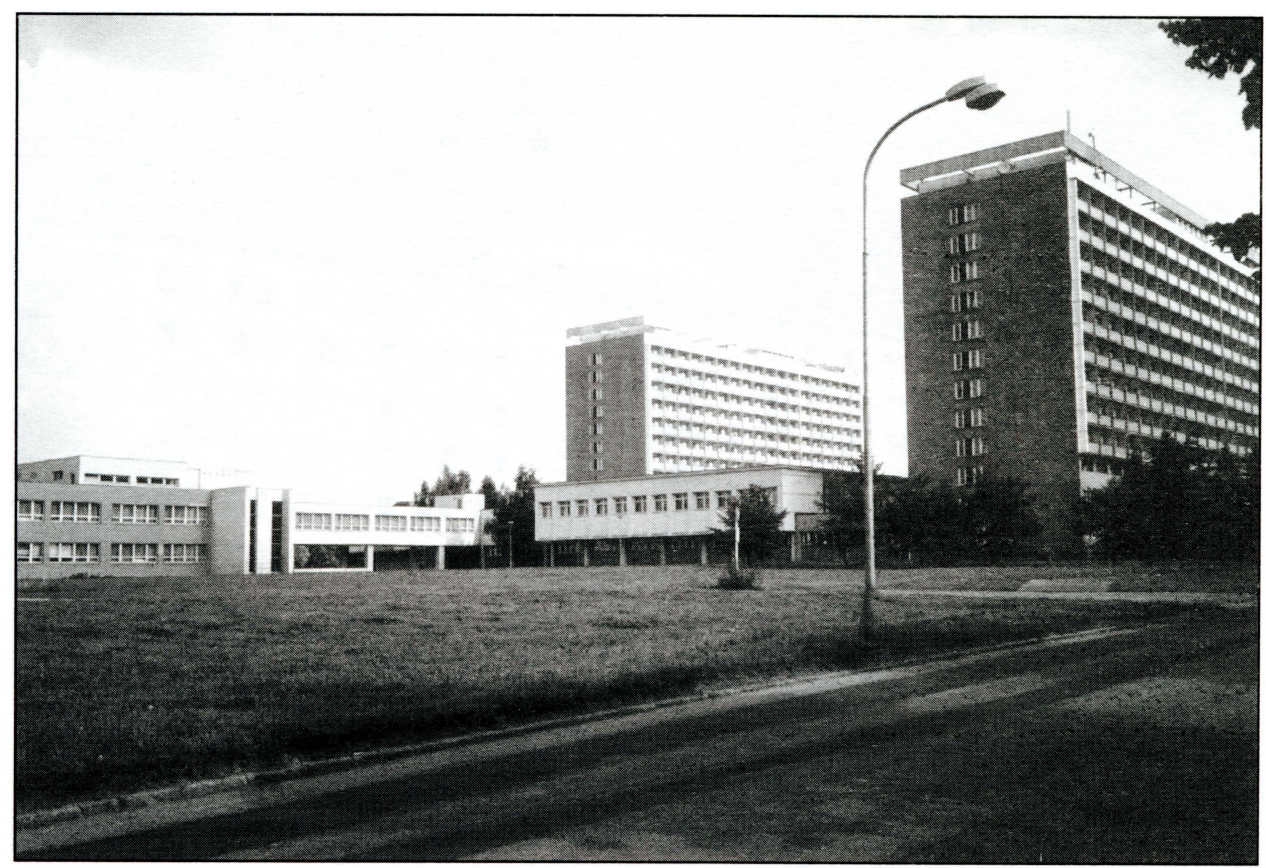

Fig. 5 - Karviná: new spa buildings in the quarter Hranice (Photo by A. Vaishar)

extended with the recent construction of public buildings in Karviná including former House of the District Committee of the Communist Party of Czechoslovakia, in which seats the Faculty of Commerce and Enterprise of the Silesian University at the present time. On the other hand, the original village of Karviná practically ceased to exist due to undermining which was most intensive here in the entire Ostrava region.

Until the mid-20th century, the territory of Havírov had only rural seats of which the most important one was Sumbark. The area was very well suited for the construction of a large housing estate after 1945 since it was situated already outside the mining territory but yet within its favourable reach. The main core was built in the cadastral area of Dolní Bludovice in the 1950s and represents a masterpiece of socialist realism. Unlike Poruba, which truly copied Soviet models, the architecture of Havírov (Fig. 6) also includes some elements of Czech national arts. The seat came into existence with a favourable spatial arrangement. However, the construction of flats was at that time accompanied with a considerably delayed building of infrastructure and Havírov was therefore rather a lodging place than a real town. The original neighbourhood was later extended with a pre-fab part of the town with already loosened structure in the period between the 1960s - 1980s. Thanks to a lot of urban greenery Havírov can be considered the most successful deed of urbanization in the former socialist Czechoslovakia. Nowadays, Havírov, once the youngest town of the Republic, has the oldest population of the whole set investigated (17.77\% of population in the postproductive age).

Although Orlová was in historical terms one of the most important places in the north-west of the Těšín District, it became town only in the year 1922 . The original colonization in the Middle Ages was of scattered character, 


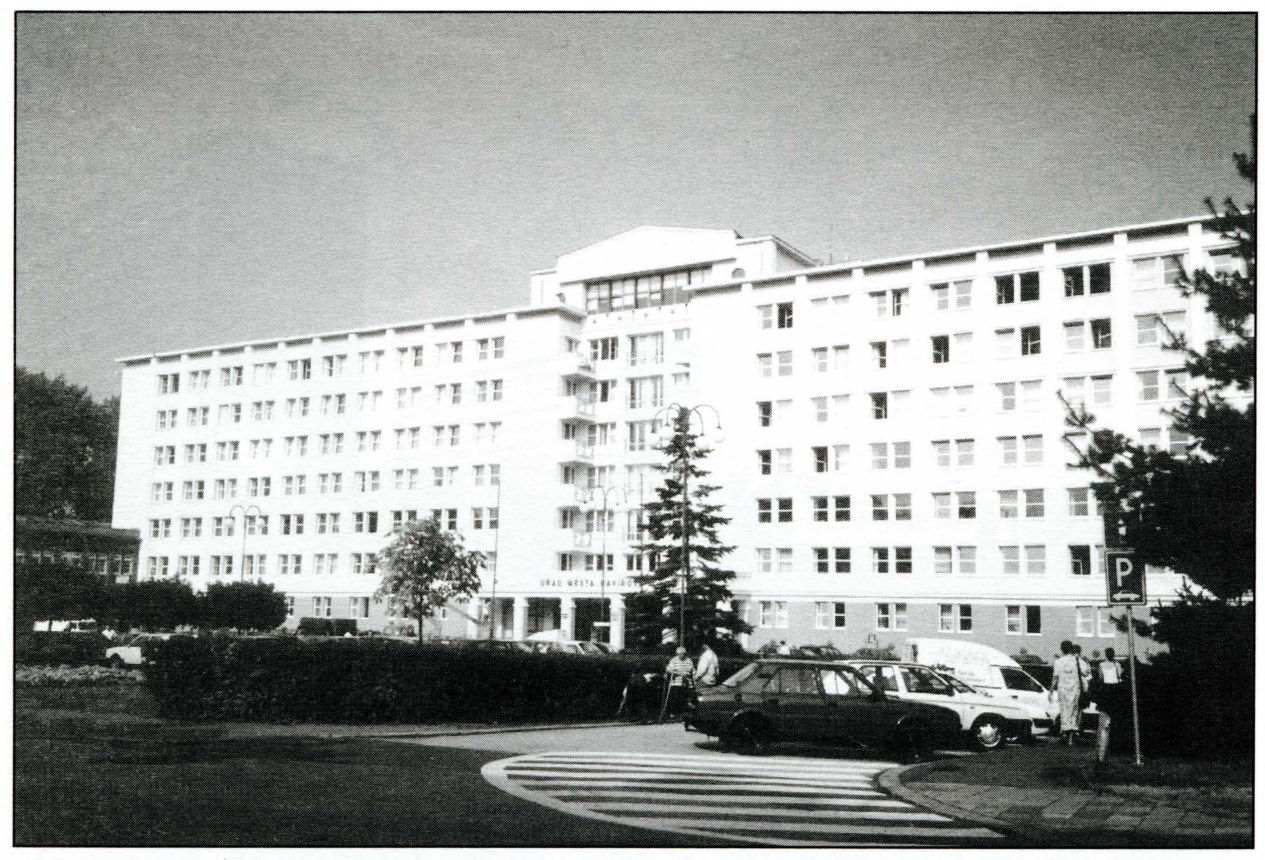

Fig. 6 - Havířov: the town hall (Photo by A. Vaishar)

organized along water courses and transit roads. The germ of Orlová was a monastery on whose place a country chateau was built after the monastery had been abolished. The situation changed by coal mining, which started in the first half of the 19th century. The connection to the original route of the Košice-Bohumín railway was of key importance.

The majority of incrementing houses in the $2^{\text {nd }}$ half of the 19 th century and in the first half of the 20th century appeared due to the construction of miner colonies of which the Monasterial Colony still exists in the devastated condition (Fig. 7). Although the whole complex had a considerably high amount of inhabitants, the residential structure was still scattered and was crossing the mining pits, spoil banks and railway sidings. Even after having been raised to a town, it was only the square that was of urban nature. Consequences of undermining started to show in the second half of the 20th century. The population in Orlová markedly dropped, the main railway track was moved outside the town limits. A new housing estate with infrastructure came into existence to the north-west of Orlová in the cadastral area of Horní Lutyně the new urban unit being nearly without any town-forming elements.

Těšín in its important strategic location was a centre of the medieval principality. Its main part stretched on the right (Polish) bank of the river Olza. In terms of traffic important left bank part was of rural character. Housing parts were distributed along the main roads. Municipal buildings started to be built in this portion of the town as late as in the 19th century. An important breaking point was the construction of the railway in 1867-69 and its extension to Žilina in the year 1871. Český Těšín came into existence in 1920 when the Olza River became state border.

As soon as Český Těšín was constituted, the then Czechoslovak government built a new representative town the reasons being prestigeous 


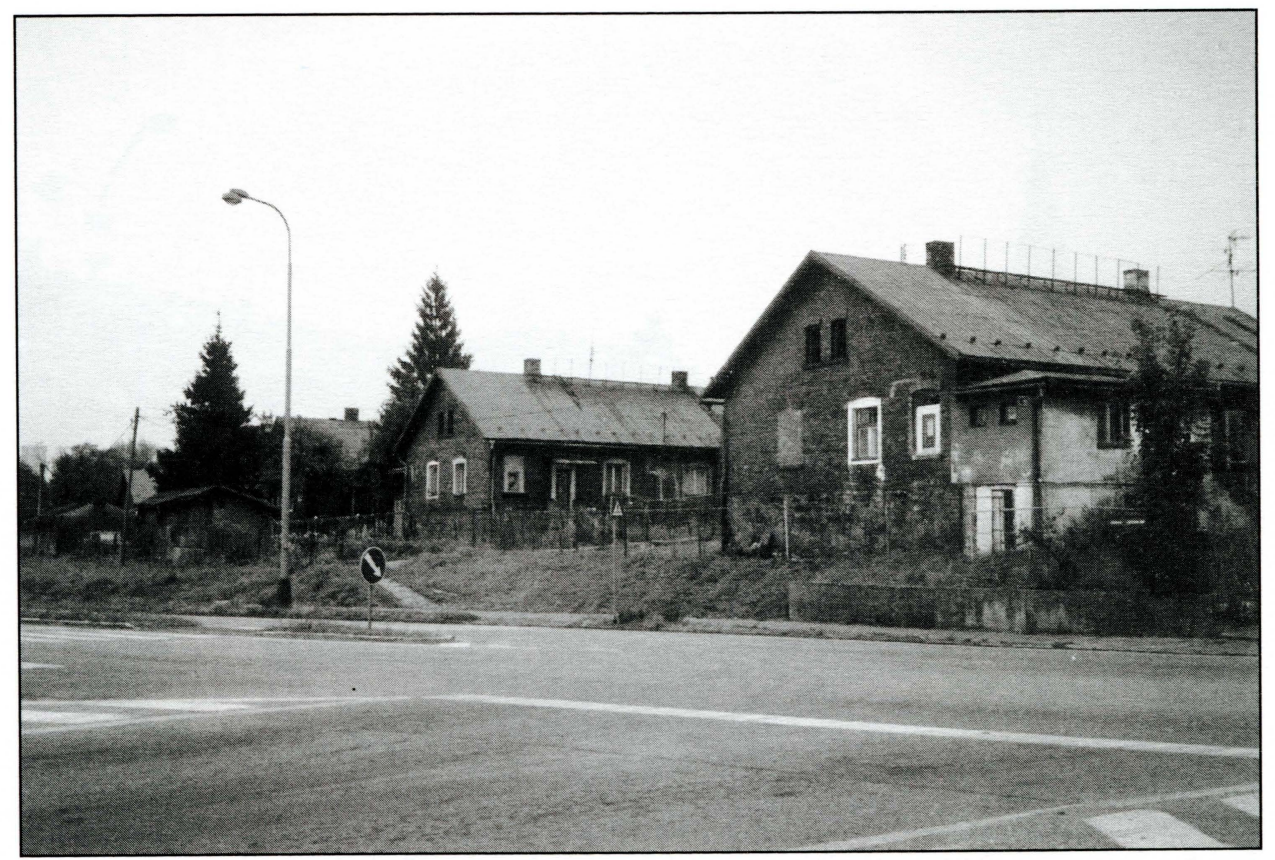

Fig. 7 - Orlová: an old miners settlement (Photo by A. Vaishar)

and strategic. The housing character documents the Czechoslovak urbanism from the time between the two wars. Socialist housing quarters are not too compatible with the housing style from between the wars. Ceský Těšín/Cieszyn is a typical twin town, which developed after splitting the original town into two by the state border.

While Starý Bohumín is an insignificant small town situated on the periphery of the region, stagnating since the mid-19 $9^{\text {th }}$ century, the functional centre of Bohumin dwells in Nový Bohumín, situated in the entirely flat landscape of the Ostrava basin. Until the 19th century, the territory had a mainly forest landscape little affected by human activities. A railway station, which soon became the most important railway junction in the Ostrava region was built in 1847. The railway station linked up with a number of chemical and metallurgical enterprises. In the NW direction a town was aligned which was built of red bricks (Fig. 8). Core margins showed a more chaotic built-up area of workmen's colonies and one-family houses. Panel housing quarters were constructed especially in the second half of the $20^{\text {th }}$ century in the north-west.

Each of the mentioned five mesoscale towns of the Karviná district apparently has a different history and origin. While Karviná grew up from the typical historical small town of Fryštát, Bohumín is the example of a new town founded in the industrial period; Havírov was newly founded as a genuine housing town in the period of Socialism, Orlová is the case of an expressive concentration of settlement and has never had the character of urban facility, and Český Těšín is an artificially created town after splitting the original seat with the state border. Although all the above mentioned towns have prevailing panel blocks of flats, it is well possible that the different historical development will show in the future - after the consequences of mining activities fade away. 


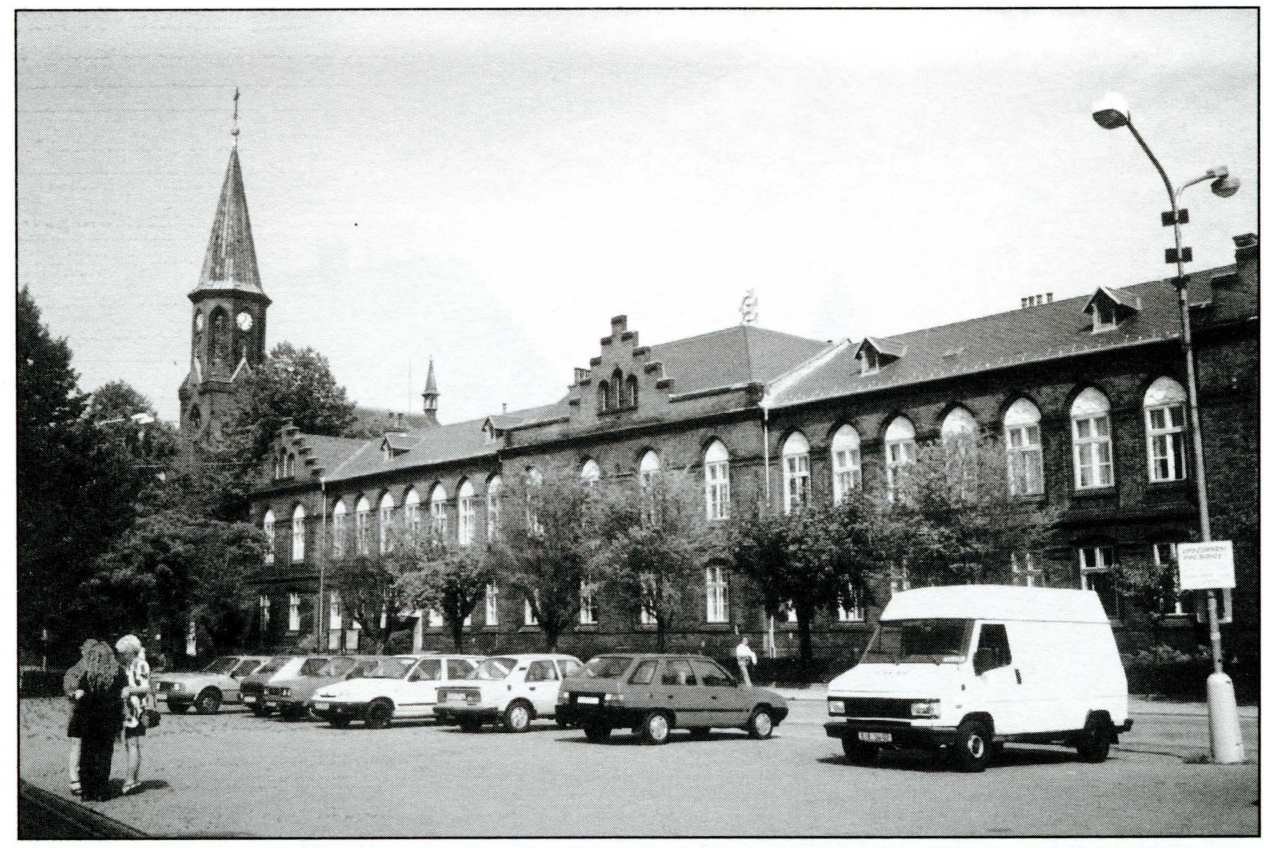

Fig. 8 - Bohumín: the town hall in the part Nový Bohumín (Photo by A. Vaishar)

The most important town of the conurbation outside the Karvina district is Frýdek-Mistek. The Silesian Frýdek was founded to guard the road from Olomouc to Těšín and Cracow in the strategic location against Moravia in the 1330s. Its suburbs were at the beginning extending along the roads to Těšín and Fryštát. The new-age development in the $19^{\text {th }}$ century was connected with textile industries in the town and metallurgical industries in the surroundings and first of all with the connection to the railway in 1871 . The town's development on the industrial basis continued also in the period between the wars. Extensive building of pre-fabricated housing quarters, which remodelled the original town structure, occurred in the 1980s. Destructive appeared to be consequences of a new highway with aboveground crossings which liquidated the sub-central part of the town. Nevertheless, the historical core of the town remained preserved.

The Moravian Místek came into existence some time later as a market and craftsmen's town situated on the important road leading from Moravia via Frýdek to Těšín and Galicia. Its development connects with draper's trade and weaving in the 18th century. These were followed by the development of other textile industries in the second half of the 19 th century, which was the time to see a rapid growth of residential and infrastructural parts of the town, which continued between the wars and the town achieved a representative character in the 1930s. During the 1960s - 1980s, Místek was afflicted with a massive panel reconstruction. Four new pre-fabricated housing quarters took a sacrifice of the sub-central urban built-up area in addition to the historical square. The town of Místek took upon the appearance of an extensive neighbourhood, cut through with broad communications.

Another large town of the conurbation is Trinec. Before the foundation of iron works, Trrinec was an unimportant rural seat in the foothills of the 
Beskids Mts., making its bread primarily from agriculture. Localization factors speaking for the foundation of metal works in the first half of the 19th century was sufficient water in the Olše River, abundant timber in the surrounding woods, deposits of limestone, iron ore, building stone and brick loams as well as a sufficient labour force in the densely populated region. Opening the Košice-Bohumín railway in 1871 was of crucial importance. The growing population called for extensive building of flats and infrastructure. The construction works culminated in the 1970s in socialist housing quarters. Třinec, which is situated on an important highway from Český Těšín to the state border in Mosty $\mathrm{u}$ Jablunkova is a starting point for tourists arriving to the Beskids Mts.

\section{General evaluation of the historical development of settlement in the Ostrava region}

Before the start of black coal mining the Ostrava region was developing as a peripheral transit region in complex conditions on the contact point of Czech, Polish and German ethnic groups and a range of feudal and clerical concerns. The situation was corresponded to by the settlement, dwelling on several important centres of which we should mention Opava, Těšín, Nový Jičín and Frýdek. More important seats were as a rule rising at crucial transit roads. Leading branch of economy was agriculture, later drapery particularly in the foothills of the Beskids Mts. A number of today's important towns were at those times rural seats.

Black coal mining meant an essential reconstruction of the settlement, unprecedented in our conditions. Individual stages of this process were described by Vičar (in Voráček et al. 1973). The developing coal mining first instigated metallurgical production and later other industries such as power generation industry, chemistry, engineering, and the Ostrava region became a fuel, power and iron base of the Austrian-Hungarian monarchy, which stimulated the construction of a railway connection between Vienna and Cracow. The centre of settlement was gradually displaced to Ostrava and to the space situated in the eastern direction from the town itself, the extent and form of the shift greatly remodelling the original residential structure.

Similar tendencies continued also in the socialist period in the first half of which the development of the Ostrava region was a priority. Huge housing quarters and whole new towns were arising in place of the spatially limited miners' colonies, which however missed and are missing up to these days some basic town-forming elements. Immigration from the surroundings and from the whole country reached enormous volumes of people. Mining and industrial activities were ate the same time intensifying which showed in the devastation of natural environment. Mining took a sacrifice of numerous original seats. The landscape was interwoven with a network of overdimensioned road communications. Several dam lakes were built. The population was characterized by above-standard financial income that was however not corresponded to by the achieved stage of social and cultural development. The society's attention beginning to turn to other directions towards the end of the socialist period, it began to be ever more clear that the developmental potential of the Ostrava region - based on heavy industry- was approaching depletion. 
The transition to market economy brought several important impulses for the Ostrava settlement system. It was first of all a structural reconstruction of the economic base in the region. Coal mining activities were closed in Ostrava and gradually slowed down in the Karviná area. A majority of industrial giants in the region have serious economic problems. Hamilton (1999) differs three types of surviving of old industrial enterprises in new conditions. Main concerns in the Ostrava region correspond to his category of the paternalistic enterprises, which suffer from technological backwardness and preceding exclusive relation to the COMECON markets, which have too many workers and are deeply in debts, but which are able to reach a massive state subsidy as flagships of the national industry, ensuring employment. Czechia overtook the German model, in which banks are the main shareholders of such enterprises.

Along with the cardinal requirement of improving labour productivity the labour force is released from industries at such a rate that it is far not possible to absorb the redundant people from industry by the formerly under-sized services. According to running results of the 2001 population census, there are $72.6 \%$ of economic active people in Ostrava employed in different branches from agriculture, forestry, water management, mining and processing industries (in Prague $87.2 \%$, in Brno 80.1\%). In other towns in the Ostrava region, the values of this coefficient fluctuate between $57.2 \%$ in Třinec and $68.5 \%$ in Český Těšín.

The situation of the Ostrava region was geopolitically affected with the split of Czechoslovakia in 1993. The area once again finds itself situated on the borderland periphery, far from the main seats and from the western state border, which represents a contact point with advanced Europe.

The panel housing quarters do not meet requirements of the ageing population for qualitative dwelling any longer. This is why the population from large seats moves to small towns and large and mesoscale villages, which however corresponds with the national trend. Prospective in this direction appears to be a certain tendency to displace a part of the population to seats in the foothills of the Beskids Mts.

A part of towns in the Ostrava region lost their up to now main functions and badly struggle to find a compensation. The settlement cannot return back to the standard structure existing before the development of mining but at the same time cannot go on in the existing form.

\section{Present prospects of main settlement centres in the Ostrava region}

We have to realize that industry is no more decisive for sustained prosperity and position of important settlement centres in the residential structure; it is rather tertiary and quaternary functions. Industries are justified in the form of advanced technologies linked up with the scientific and research base or as a complementary branch to employ a part of the labour force. It follows unambiguously that towns, which based their perspective on heavy industry will soon have to face retreat from glory.

At the present time, all mentioned towns of the Ostrava region fight with the problem of a relatively high unemployment (Table 1). The unemployment has some peculiarities in this region. The lost labour opportunities were very 
Tab. 1 - The level of unemployment $(\%)^{2}$ in selected towns in the Ostrava region Town

\begin{tabular}{|l|c|c|c|c|c|}
\hline & 30.6 .1999 & 31.12 .1999 & 30.6 .2000 & 31.12 .2000 & 30.6 .2001 \\
\hline Ostrava & 14.4 & 15.9 & 16.4 & 16.6 & 16.2 \\
Karviná & 17.8 & 18.8 & 19.0 & 18.9 & 18.6 \\
Havírov & 13.7 & 15.1 & 16.1 & 16.4 & 16.3 \\
Bohumín & 13.6 & 14.7 & 15.9 & 16.2 & 15.5 \\
Český Těšín & 16.5 & 17.5 & 17.3 & 17.3 & 17.4 \\
Orlová & 18.4 & 19.9 & 20.7 & 20.4 & 19.7 \\
Frýdek-Místek & 14.7 & 16.4 & 16.5 & 15.4 & 14.9 \\
Třinec & 10.5 & 11.4 & 11.4 & 12.2 & 12.2 \\
\hline
\end{tabular}

specific, socially preferred with high incomes in the last political system. Even in the $1^{\text {st }}$ half of 2001 amounted the average income in Ostrava $14999 \mathrm{CZK}$ per one employee, which responds the $4^{\text {th }}$ place among Czech districts ${ }^{1}$. From it follow structural problems of employment, worse preconditions of requalification, less motivating milieu for foreign investors, who are accustomed to a low price of labour force in regions with a high unemployment etc.

The level of unemployment generally relates to the level of education. In this respect is the situation in Ostrava unfavourable. The share of people elder than 15 years with the university education reaches in Ostrava $10.5 \%$, which is at the least of all comparable cities of Czechia (Prague $23.2 \%$, Brno $17.9 \%$, Plzen $12.5 \%$ ). Among the middle-size towns in the Ostrava surroundings, the most favourable education level has Frýdek-Místek (9.2\%). This value is better than in other towns impacted with the restructuring of heavy industry (Kladno, Most, Teplice, Ústí nad Labem), but by one third worse than in classical Czech middle-size towns (Olomouc has $15.5 \%$ people with an university education). Karviná has the lowest level of education among the Czech middle-size towns at all (4.8\% graduated people). Also small towns in the Ostrava region have low shares of graduated inhabitants (the best situation being in Český Těšín - $8.6 \%$ graduated people).

A great handicap for the majority of towns in the Ostrava region is the absence of cultural and historical values and in some cases also the absence of significant signs of town characteristic. Another problem is the nonexistence of unambiguous and natural gravity centres of the town-hinterland type. The population's social structure is unfavourable, too - with people being still used to work as employees with a high level of social advantages and allowances.

Another factor to be taken into account is the unfavourable environmental situation which -although showing some tendencies to improvement- still remains very bad in the comparison with other regions and furthermore does not create good image for the region. In 2000, exhalations in the district of Ostrava-town amounted 2565 tons of solid substances (most in Czechia), 14676 tons of $\mathrm{SO}_{2}, 11228$ tons of $\mathrm{NO}_{\mathrm{x}}$ (comparable only with districts of northern Bohemia and Pardubice) and 70465 tons of CO (district of FrýdekMístek occupies the 2nd place ${ }^{3}$. Taking into account the small area of the district, exhalations per $1 \mathrm{~km}^{2}$ are extraordinary. Such a situation does not create good image of the region. A similar situation was found in the Ruhr

\footnotetext{
Data of the CR Ministry of Labour and Social Affairs

the webpage of the Regional Information System of the Ostrava Region: (6.5.2002)

data of the Czech Ministry of Environment
} 
Basin (Maier-Beck 2000). A crucial issue is apparently the replacement of industries with other functions - if possible at a diversified branch, organizational and size structure.

The city of Ostrava (population $319162^{4}$ ) itself is exceptional in its entire system of settlement since it is an unambiguous centre of the whole region. It is also a provincial town, seat of two public and one private universities and a range of other quaternary activities, today also a centre of cultural and social life in the region and a partner for contacts with the opposite centre of Polish Upper Silesia Katowice. A certain advantage is the built-up technical infrastructure. Although the required reconstruction of industrial town quarters is costly, it makes it possible to go for modern concepts. This also applies to a possibility of creating of a new city centre in place of the former Karolina coke plant. A pre-requisite for the prosperity is an improved connection to the rest of the country by means of a speed motorway and a better passability of border-crossings to Poland. Another advantage is the existence of the Mošnov airport.

With no exception the towns of the Karviná district will most probably have to face reduced population, which is going to be rather considerable in some cases. Although the number of inhabitants is an important index as it defines the size of the local market, the quality of urban functions is of conclusive significance. Viewed from this point, the greatest chances seem to be those of the district town. It is worth pointing out at this place that it will not be the administrative function because the districts are expected to get extincted in a few following years. A decisive fact is that Karviná (population 65 491) has - as the only one of these centres - its historical core in Fryštát to derive the town's cultural and historical character. The Faculty of Business Economics of the Silesian University (which could improve the bad educational situation in the town), the functional spa of Darkov with the new premises in Hranice, the new industrial zone of Nove Pole with the potential of $2.5-3$ thousand jobs and the border crossing should lay foundations to the necessary multifunctional character of Karviná. The existing housing quarters are expected to be a problem in the future.

The future profile of Český Těšín (population 26572 ) as a cultural centre of Polish minority with the polygraphic tradition, town of secondary schools, theatre with the Czech and Polish scenes, the busiest road border-crossing with Poland, railway and highway junction and the seat of somewhat more diversified industries than in other centres of the Karviná district can be relatively satisfactory. In terms of culture and history the town can link up with the historical tradition in spite of the fact that the former centre of principality is on the Polish side of the border.

The other three towns are problematic in terms of their future prosperity. The future function of Havírov (population 87021 ) is unclear with the role of housing quarter for coal mines and industries in Ostrava practically ending. The dwelling environment of the town is little attractive and the town's hinterland is minimal. The only industrial enterprise of shoe-making industry does not produce. The fact is that the town of this size requires a considerable amount of jobs to serve itself but the need is supposed to fall with the falling number of inhabitants. The document Strategy of the town of Haviŕov does not count with an extraordinary strengthening of town-forming

4 population data see the running results of the 2001 population census, Czech Statistical Office 
functions anyhow, with the foundation of a university being only at the 8th place in the list of priorities and considered little realistic in the same document.

Bohumín (population 23 408) grew up as a railway junction; its present developmental impulses are however those of motorways. The plan to extend the broad-gauge railway from Poland and to build a terminal for trading of western Europe with Ukraine and Russia is a certain hope. Industrial enterprises in the town face serious structural problems their fate being uncertain and will require a considerably reduced labour force even in the case that their significance is successfully restored. Most problematic seems to be Orlová (population 35 063) which is a neighbourhood with no unambiguous urban character and with no town-forming functions.

Frýdek-Místek (population 61 423) is another town that can build on the historical tradition. As a district town it has a relatively large gravity area which is however demarcated by the gravitational force of Ostrava in the north while reaching into the attractive Beskids Mts. in the south-eastern direction. The town has got the required social and cultural infrastructure its industrial structure being more diversified. It is situated on a relatively favourable traffic position.

Třinec (population 38980 ) is clearly an industrial town whose past prosperity consisted in one giant enterprise. The town struggles for diversification within the framework of project supporting the Baliny industrial zone. In the future, the town might participate in the development of travelling and tourism in the foothills of the Beskids, which can be further fostered by the road border-crossing in Dolní Lištná.

It is to be expected that the region will record reduced population practically in all important centres. Although the developmental trend is anticipated also in other regions of the country, the Ostrava region will have the tendency further intensified by immigration from the region and redistribution of inhabitants within the region. The panel housing quarters will most probably be abandoned in a very distant time horizon with their inhabitants preferring settlement in smaller seats. The important centres of settlement will most probably have to face a conflict of competition. While the position of Ostrava in the residential structure of north-eastern Moravia is quite clear, the other centres will fight for next places in the hierarchy. Successful are going to be the centres that will be capable of using competitive advantages and eliminating disadvantages.

The pre-fabricated or brick housing quarters represent a considerable problem. This type of dwelling houses can be found throughout Europe including the western Europe. However, the problem of Ostrava is a high concentration of these housing estates, monotonous and monofunctional character of dwelling zones, poor spatial arrangement of apartments and poor workmanship of construction. There are $85.5 \%$ o flats in blocks (in Brno $80.7 \%$, in Plzeň $83.7 \%$ ). More flats in blocks can be found in Prague, but only $30.6 \%$ of such flats in Prague are in prefabs, whereas the same datum for Ostrava reaches $41.6 \%$. Smaller towns should theoretically have more flats in one-family houses, but Karviná (89.8\% flats in blocks) and especially Havírov (90.5\% of all flats in blocks) are beyond of this presupposition. Shares of flats in prefabs among flats in blocks exceed $50 \%$ in all mentioned towns of the Ostrava region except of Český Těšín and Bohumín.

The result is an anonymous dwelling environment with houses requiring extraordinarily high energy supply, often at a very bad condition. Technical 
equipment of prefabs (central heating, laying on the gas, bathrooms and WC) is though almost complete, but this advantage is redeemed with unfavourable values of the square standard of living. According to the running results of the 2001 population census, the average living square per person in Ostrava represents $16.9 \mathrm{~m}^{2}$, in the other mentioned towns of the Ostrava region it fluctuates between $17.6 \mathrm{~m}^{2}$ in Český Těšín and quite extreme $15.3 \mathrm{~m}^{2}$ in Orlová and $14.9 \mathrm{~m}^{2}$ in Karviná. Of comparable big cities, the lowest living square per capita is in Brno $\left(17.8 \mathrm{~m}^{2}\right)$, of the middle-size towns in Moravia in Zlín $\left(17.5 \mathrm{~m}^{2}\right)$. Reconstruction of these parts of towns in the Ostrava region is necessary but at the same time very costly and limited by the existing structure of the built-up area. The problem would require a separate study.

Nevertheless, we do not conclude that a way out would lead through the replacement of dwelling houses with one-family houses. This was the model chosen by the U.S.A. after the WWII, which resulted in serious traffic, energy and social problems. Being good for families, the one-family houses are less fitted for the ever increasing percentage of single people, childless couples, incomplete families and social cases notwithstanding the fact that it will be necessary to somewhat increase people's motility. All these facts indicate that a large portion of the population will still have to live in apartment houses.

The Ostrava region is not the first region of coal mining and heavy industry to pass through the stage of restructuring. The Midlands or the Ruhrgebiet have already gone through the transition, be it in different social conditions. The problem is therefore not perceived as a priority in the world literature. At a global scale, large cities rather struggle with uncontrolled growth in the developing world and with efforts to preserve identity and cultural values in the western Europe and northern America. The problem of restructuring the old industrial regions is at the present time more or less an issue of postsocialist countries. Similar problems are faced for example by the Leipzig region in the eastern Germany with extensive open-cast coal mining and linking industries (Kabisch 1997). There is an expressive differentiation of individual seats there occurring according to new conditions and towns' capabilities to accommodate to the changed conditions.

In respect of further development of the settlement in the Ostrava region we can ask three questions: What will be the future development of the main centre in the Ostrava region? What functions and positions will have the other centres in the region in the residential structure? What is the measure to what it would be possible to revitalize the function of the original provincial cores in the region?

\section{References:}

BURDACK, J. (1993): Birmingham und das Black Country. Europa Regional 1, No. 2, pp.31-39.

DÜRR, H., GRAME, J. (1993): Das Ruhrgebiet im Wandel. Ruhr-Universität Bochum, $207 \mathrm{p}$.

CHARVÁT, M. (1992): Ostrava Conurbation - Planning and Reality. Sborník České geografické společnosti, 97, No. 2, pp. 88-96.

HAMILTON, E. (1999): Transformation and space in central and eastern Europe. The Geographical Journal, 165, No.2, pp. 135-144.

KABISCH, K. (1997): Siedlungsstrukturelle Einschnitte infolge des Braunkohlebergbaus. In: Ring, I. (ed.): Nachhaltige Entwicklung in Industrie- und Bergbauregionen - eine Chance für den Südraum Leipzig? B.G.Teubner Verlagsgesellschaft Stuttgart - Leipzig, pp. 113-137. 
KLOSOWSKI, F., RUNGE, J., PROKOP, R. (1997): The spatial and functional structure of the Katowice voivodship (Poland) compared with the Ostrava - Karviná industrial region (Czech Republic). Acta Facultatis Rerum Naturalium, Geographia-Geologia No.5, University of Ostrava, pp. 169-190.

KUČA, K. (2000): Města a městečka v Čechách, na Moravě a ve Slezsku [Towns and small townships in Bohemia, Moravia and Silesia]. Volume IV. Libri Prague, 939 p.

MAIER, J., BECK, R. (2000): Allgemeine Industriegeographie. Justus Perthes Verlag Gotha, 295 p.

PACIONE,M. (2001): Urban Geography. Routledge London/New York, 663 p.

Program rozvoje územního obvodu Moravskoslezského kraje 2001 - 2004 (2001). Agentura pro regionální rozvoj a.s. Ostrava.

ŠINDLER, P. (2001): Image měst Ostravského kraje a jeho význam v regionálním rozvoji. In: Baran,V. (ed.): Premeny Slovenska v regionálnom a didaktickom kontexte. Fakulta prírodných vied UMB Banská Bystrica, p. 102-105.

VORÁČEK, V. et al. (1973): Vliv hospodářské činnosti na životní prostředí Ostravska [Impact of economic activities on environment in the Ostrava region - research report]. Institute of Geography, Czechoslovak Academy of Sciences Brno, $476 \mathrm{p}$.

VYSTOUPIL, J., WECŁAWOWICZ, G. (1987): Vnitřní struktura Katovic a Ostravy [Internal structure of Katowice and Ostrava]. Sborník české geografické společnosti, 92, No. 1, pp. 1-18.

\section{Sum m a r y}

\section{VÝVOJ OSÍDLENÍ OSTRAVSKA A MOŽNOSTI JEHO RESTRUKTURALIZACE}

Ve velkoplošných regionech těžby uhlí se od 19. století vytvářelo specifické osídlení. Původní typická středisková soustava měst a jejich zázemí byla přemodelována a vznikla mozaika šachet, hornických kolonií (později panelových sídlište) a průmyslových podniků, protkaná hustou sítí infrastruktury. Tyto regiony se staly ekonomickými základnami svých zemí, za což však zaplatily těžkými environmentálními problémy. Ve 2 . polovině 20 . století došlo $\mathrm{v}$ souvislosti $\mathrm{s}$ vývojem výrobních sil $\mathrm{k}$ postupnému snižování významu těžkého průmyslu a ekonomika pánevních regionů západní Evropy procházela restrukturalizací. V souvislosti s ní se měnil i obraz osídlení.

V bývalých socialistických státech byl proces úpadku těžkého průmyslu zpomalován zásahy státu. Osídlení v pánevních oblastech tudíž mohlo reagovat na změněné podmínky jen minimálně. Takovým př́ípadem je i Ostravsko, kde na těžbu černého uhlí navazovala metalurgie železa, těžké strojírenství a chemický průmysl. Historický vývoj této oblasti byl kromě těžby modifikován i polohou na hranici styku české, polské a německé kultury v kontextu historických událostí 19. a 20. století. Na počátku období ústředně ř́zené ekonomiky patřil rozvoj Ostravska $\mathrm{k}$ prioritám tehdejšího režimu. Velké investice byly vloženy zejména do výstavby průmyslových podniků a bytů, zatímco sociální infrastruktura zaostávala. Počet obyvatel se v důsledku intenzivní imigrace rychle zvyšoval. Pracovní síla byla charakterizována nadprůměrnými přijmy, ale podprůměrnou kulturní úrovní. Životní prostředí regionu patřilo k nejhorším v celé Evropě.

Teprve v souvislosti se společenskými změnami po roce 1989 dochází k restrukturalizaci ekonomické základny regionu. Těžba uhlí v samotné Ostravě byla ukončena, v jejím okolím utlumena. Jedním $\mathrm{z}$ hlavních problémů regionu je odlehlost od centra a poloha na východní hranici rozděleného státu. Jednotlivá města hledají nové funkce a místa v systému osídlení.

Ostrava se vyprofilovala jako jednoznačné středisko oblasti s krajskou funkcí, se třemi univerzitami a dalšími kvartérními funkcemi. Je i kulturním a společenským centrem a také partnerem pro kontakty $\mathrm{s}$ protějším střediskem polského Horního Slezska Katovicemi. Výhodou je vybudovaná technická infrastruktura. Nutná rekonstrukce průmyslových částí města je sice finančně náročná, ale umožňuje zvolit koncepčně moderní řešení. To se týká i možnosti vytvoření nového centra města. Předpokladem prosperity je zlepšení napojení na zbytek státu dálniční komunikací a zlepšení průchodnosti hraničních přechodů do Polska. Výhodou je existence letiště Mošnov.

Historický vývoj ostatních důležitých středisek Ostravska byl rozdílný. Ukazuje se, že největší šance má Karviná, která má historické kořeny a k nim administrativní, vysokoškolskou a lázeňskou funkci. Jen o něco hưře je na tom další okresní středisko Frýdek-Místek, které vzniklo z historického dvojměstí. Problematický je Havířov, který 
vyrostl jako socialistické město na zelené louce a postrádá většinu městotvorných funkcí. Podobně ani Orlová nikdy nebyla plnohodnotným městem. Český Těšín vyrostl $\mathrm{z}$ prestižních důvodů $\mathrm{v}$ první polovině 20 . století, dnes může těžit $\mathrm{z}$ pozice kulturního střediska polské minority. Bývalé středisko hutnictví Třinec může rozšírít své funkce jako východisko do rekreačních terénů Beskyd. Železniční uzel Bohumín zamýšlí revitalizovat svou funkci výstavbou překladiště na konci širokorozchodné železnice z Polska a Ukrajiny.

Jako v celém státě dochází i na Ostravsku k suburbanizačním a dezurbanizačním jevům, které jsou charakterizovány migrací obyvatelstva $\mathrm{z}$ velkých měst do malých měst a na venkov. V souvislosti s tím je důležitá otázka dalšího vývoje malých měst Ostravska, která byla dřive ve stínu velkých průmyslových středisek.

Obr. 1 - Ostravsko v rámci Česka

Obr. 2 - Ostravská aglomerace

Obr. 3 - Ostrava - Poruba: monumentální architektura podle sovětského vzoru (foto A. Vaishar)

Obr. 4 - Karviná: staré centrum Fryštát (foto A. Vaishar)

Obr. 5 - Karviná: nové lázeňské objekty ve čtvrti Hranice (foto A. Vaishar)

Obr. 6 - Havířov: radnice (foto A. Vaishar)

Obr. 7 - Orlová: staré hornické osídlení (foto A. Vaishar)

Obr. 8 - Bohumín: radnice v městské části Nový Bohumín (foto A. Vaishar)

(Author is with Institute of Geonics, Academy of Sciences of the Czech Republic, Branch Brno, Drobného 28, 60200 Brno, Czechia.) 